\title{
Profil Zat Besi Ibu Hamil di Daerah Endemis Malaria
}

\author{
Profile of Maternal Iron in Malaria Endemic Areas
}

\author{
Rostika Flora* Bina Melvia** Sigit Purwanto**
}

\begin{abstract}
*Program Studi Ilmu Biomedik Fakultas Kedokteran Universitas Sriwijaya, **Program Studi Ilmu Keperawatan Fakultas Kedokteran Universitas Sriwijaya
\end{abstract}

\begin{abstract}
Abstrak
Pada saat kehamilan, terjadi peningkatan kebutuhan zat besi $(\mathrm{Fe})$ yang diperlukan untuk meningkatkan jumlah sel darah merah ibu dan membentuk sel darah merah janin dan plasenta. Apabila kebutuhan zat besi ini tidak terpenuhi, akan terjadi anemia defisiensi besi. Ibu hamil yang tinggal di daerah endemis malaria rentan terinfeksi malaria, yang berdampak terhadap anemia pada kehamilan. Penelitian ini merupakan penelitian deskriptif dengan desain potong lintang yang bertujuan untuk mengetahui gambaran profil zat besi pada ibu hamil yang berada di daerah endemis malaria vivax kota Bengkulu. Pemeriksaan mikroskopis malaria dan pengambilan sampel darah dilakukan untuk pemeriksaan profil zat besi terhadap 55 orang ibu hamil trimester II dan III yang mempunyai riwayat malaria di 5 wilayah kerja puskesmas. Data yang diperoleh kemudian dilakukan analisis univariat. Pada ibu hamil yang tidak terinfeksi malaria tetapi mempunyai riwayat malaria, 90,5\% mengalami anemia, 41,5\% mengalami penurunan kadar Total Iron Binding Capacity (TIBC), dan 17\% mengalami penurunan kadar Fe serum. Ibu hamil yang terinfeksi malaria vivax selain terjadi penurunan kadar hemoglobin juga disertai dengan penurunan kadar Fe serum dan kadar TIBC. Pada ibu hamil yang menderita malaria falsiparum, terjadi penurunan kadar hemoglobin $(\mathrm{Hb})$ dan kadar TIBC tetapi tidak disertai dengan penurunan kadar Fe serum. Ibu hamil yang terinfeksi malaria maupun yang mempunyai riwayat terinfeksi malaria mengalami anemia pada kehamilan.

Kata kunci: Anemia, kehamilan, malaria, zat besi
\end{abstract}

\section{Abstract}

During pregnancy, the need of iron increase significantly. Iron is needed for increasing the amount of mother's red blood cell and form the red blood cell of fetus and placenta. If this iron needs is not fulfilled, it could cause iron deficiency anemia. Pregnant women who live in endemic malaria will be vulnerable to be infected malaria, and will cause anemia in pregnancy. This research was aimed to know iron profile in pregnant women that live in en- demic malaria area. Malaria microscopic examination and blood sampling for examination of iron profile in 55 pregnant women trimester II and III who have a history of malaria in 5 working area health centers. The data obtained was then performed univariate analysis. The results showed pregnant women who have malaria history, $90.5 \%$ are suffering anemia, decreasing of Total Iron Binding Capacity (TIBC) level (41.5\%) and 17\% Fe serum level $(17 \%)$. Pregnant women who are infected vivax malaria not only experiencing decrease of hemoglobin level but also experiencing decrease of Fe serum level and TIBC level, while pregnant woman who suffers from falciparum malaria haemoglobin $(\mathrm{Hb})$ level and TIBC are decreasing but not in serum Fe levels. Pregnant women with history of malaria infection will suffer from anemia during pregnancy.

Keywords: Anemia, pregnancy, malaria, iron

\section{Pendahuluan}

Zat besi (Fe) merupakan salah satu unsur di dalam tubuh yang sangat dibutuhkan untuk reaksi enzimatik dan metabolisme. Zat besi diperoleh tubuh melalui makanan yang dikonsumsi. Pada saat kehamilan, terjadi peningkatan kebutuhan zat besi tubuh dan infeksi parasit, seperti cacing tambang dan malaria akan memperparah kekurangan zat besi. Apabila kebutuhan tubuh tidak terpenuhi, akan terjadi anemia defisiensi besi (Iron Deficiency Anemia/IDA). IDA pada kehamilan umumnya terjadi karena zat besi pada makanan yang dikonsumsi tidak mencukupi. ${ }^{1}$

Infeksi parasit malaria sangat mudah terjadi pada ibu hamil karena perubahan sistem imunitas seluler dan imu-

Alamat Korespondensi: Rostika Flora, Program Studi Ilmu Keperawatan FK Universitas Sriwijaya, Jl. Dr. Moh. Ali Komplek Rumah Sakit Moh. Hoesin Palembang, Hp.082110351971, e-mail: rostikaflora@gmail.com 
nitas humoral, juga karena peningkatan hormon kortison pada wanita selama kehamilan. ${ }^{2}$ Pada ibu hamil, anemia yang terjadi akibat malaria disebabkan oleh plasmodium yang menginvestasi eritrosit sehingga berdampak pada penekanan produksi eritropoetin dan gangguan eritropoesis sebagai akibat produksi sitokin pada proses inflamasi. Eritrosit yang diinvestasi oleh plasmodium akan mengalami kelainan sehingga permukaan sel menjadi tidak teratur. Kerusakan eritrosit tersebut akan menyebabkan terjadi anemia, anoksia jaringan, dan hemolisis intravaskuler. ${ }^{3}$

Hampir separuh populasi penduduk Indonesia atau lebih dari 90 juta orang bermukim di daerah endemis malaria. ${ }^{4}$ Ibu hamil yang tinggal di daerah endemisitas malaria yang tinggi sangat mudah terinfeksi malaria, yang berdampak anemia pada kehamilan. ${ }^{5}$ Anemia yang disebabkan oleh infeksi malaria terjadi akibat proses penghancuran eritrosit dan penurunan proses pembentukan eritrosit (eritropoesis), sehingga menyebabkan kadar hemoglobin $(\mathrm{Hb})$ di dalam darah yang rendah. ${ }^{6}$ Salah satu daerah endemis malaria di Indonesia adalah Provinsi Bengkulu. Berdasarkan data skrining malaria pada ibu hamil dari Dinas Kesehatan Provinsi Bengkulu, jumlah kasus ibu hamil yang terinfeksi malaria vivax pada tahun 2009 adalah 230 kasus dari 20.459 ibu hamil (1,12\%). Pada tahun 2010, jumlah ibu hamil yang terinfeksi malaria vivax adalah 39 kasus dari $2.900 \mathrm{ibu}$ hamil (1,34\%), dan pada tahun 2011 berjumlah 87 yang terinfeksi malaria vivax dari $34.334 \mathrm{ibu}$ hamil $(0,25 \%){ }^{7}$

Dari beberapa penelitian, infeksi yang disebabkan oleh $P$. vivax berdampak lebih ringan daripada dengan $P$. falciparum, tetapi dapat mengancam kesehatan ibu dan janin yang dikandung. Berbeda dengan $P$. falciparum, $P$. vivax tidak terjadi perlekatan pada reseptor organ atau pembuluh darah, tetapi mempunyai kemampuan relapse setelah infeksi atau setelah pengobatan. Dalam waktu yang lama, parasit tersebut berkembang dan mengakibatkan infeksi recurrent yang berdampak pada penggunaan zat besi oleh parasit untuk proses multiplikasi yang mengakibatkan terjadi anemia. ${ }^{8}$ Penelitian ini bertujuan untuk mengetahui gambaran profil status zat besi pada ibu hamil yang berada di daerah endemis malaria vivax Kota Bengkulu.

\section{Metode}

Penelitian deskriptif yang menggunakan desain potong lintang ini dilakukan di daerah endemis malaria vivax, di Kota Bengkulu, di wilayah kerja lima puskesmas yang mempunyai data penderita malaria terbanyak di Kota Bengkulu, meliputi Puskesmas Suka Merindu, Puskesmas Padang Serai, Puskesmas Jembatan Kecil, Puskesmas Pasar Ikan, Puskesmas Kandang. Penelitian dilakukan selama enam bulan, pada periode awal bulan April 2013 sampai dengan awal bulan Oktober 2013.
Populasi penelitian ini adalah seluruh ibu hamil yang berada di wilayah kerja lima puskesmas dan sampel diambil secara accidental sampling. Ibu hamil yang memenuhi kriteria inklusi selama masa penelitian akan diikutsertakan dalam penelitian ini. Kriteria inklusi meliputi bersedia berpartisipasi dalam penelitian ini, kehamilan trimester II dan III, pernah terinfeksi malaria. Kriteria eksklusi meliputi tidak bersedia berpartisipasi, kehamilan trimester I, mempunyai penyakit infeksi lain dan kehamilan kembar. Pengambilan sampel dilakukan pada saat ibu hamil mengunjungi puskesmas untuk pemeriksaan kehamilan. Pengambilan darah juga dilakukan untuk pemeriksaan parasit malaria dan pengukuran profil zat besi.

\section{Hasil}

Selama survei, dilakukan pemeriksaan mikroskopis malaria terhadap 55 orang ibu hamil dengan riwayat pernah terinfeksi malaria. Dari 55 orang ibu hamil, didapatkan 3,6\% ibu hamil menderita malaria. Semua ibu hamil penderita malaria $(100 \%)$ mengalami anemia. Namun, hampir seluruh ibu hamil dengan malaria negatif $(90,5 \%)$ mengalami anemia. Ibu hamil penderita malaria sebagian $(50 \%)$ mempunyai kadar Fe serum yang rendah, ibu hamil dengan malaria negatif $(62,2 \%)$ mempunyai kadar Fe serum yang normal. Selanjutnya, seluruh ibu hamil penderita malaria mempunyai kadar Total Iron Binding Capacity (TIBC) yang rendah, sedangkan pada ibu hamil dengan malaria negatif $41,5 \%$ mempunyai kadar TIBC yang rendah (Tabel 1).

\section{Pembahasan}

Berdasarkan hasil penelitian, didapatkan bahwa ibu hamil yang tidak terinfeksi malaria hampir keseluruhan mengalami anemia $(90,5 \%)$. Akan tetapi, apabila dilihat dari hasil pemeriksaan kadar Fe serum dan kadar TIBC sebagian ibu hamil tersebut mempunyai kadar Fe serum

Tabel 1. Status Anemia, Kadar Serum Zat Besi, dan Kadar Total Iron Binding Capacity dengan Status Mikroskopis Malaria pada Ibu Hamil

\begin{tabular}{lclll}
\hline Profil Zat Besi & Status Malaria & Kategori & $\mathbf{n}$ & $\%$ \\
\hline Status anemia & \multirow{2}{*}{ Positif } & Anemia & 2 & 100 \\
& & Tidak anemia & 0 & 0 \\
& Negatif & Anemia & 48 & 90,5 \\
& & Tidak anemia & 5 & 9,5 \\
Kadar Fe serum & Positif & Rendah & 1 & 50 \\
& & Normal & 1 & 50 \\
& \multirow{3}{*}{ Negatif } & Tinggi & 0 & 0 \\
& & Rendah & 9 & 17,0 \\
& & Normal & 33 & 62,2 \\
Kadar TIBC & Tinggi & 11 & 20,8 \\
& Positif & Rendah & 2 & 100 \\
& & Normal & 0 & 0 \\
& \multirow{2}{*}{ Negatif } & Tinggi & 0 & 0 \\
& & Rendah & 22 & 41,5 \\
& & Normal & 26 & 49,1 \\
& & Tinggi & 5 & 9,4 \\
\hline
\end{tabular}


$(62,2 \%)$ dan kadar TIBC $(49,1 \%)$ yang normal. Menurut $\mathrm{WHO}$, anemia pada ibu hamil adalah kondisi ibu dengan kadar $\mathrm{Hb}$ dalam darahnya kurang dari 11,0 g\%. Pada kehamilan, anemia yang terjadi sebenarnya merupakan hal yang fisiologis karena dalam kehamilan jumlah darah akan bertambah banyak (hiperemia atau hipervolemia) sehingga terjadi pengenceran darah karena jumlah sel-sel darah tidak sebanding dengan pertambahan plasma darah. Bertambahnya darah dalam kehamilan sudah dimulai sejak kehamilan 10 minggu dan mencapai puncaknya dalam kehamilan antara 32 dan 36 minggu. Secara fisiologis pengenceran darah ini untuk membantu meringankan kerja jantung yang semakin berat dengan adanya kehamilan. ${ }^{9}$

Di negara-negara berkembang seperti Indonesia, kebanyakan anemia dalam kehamilan diperberat dengan adanya defisiensi zat besi. ${ }^{10}$ Menurut Manuaba, anemia ringan pada ibu hamil mengakibatkan terjadinya kelahiran prematur dan berat bayi lahir rendah (BBLR), sedangkan pada anemia berat mengakibatkan risiko morbiditas dan mortalitas pada ibu maupun pada bayi yang dilahirkan. ${ }^{11}$ Selain itu, anemia juga dapat mengakibatkan hambatan tumbuh kembang janin dalam rahim dan ketuban pecah dini. Anemia dapat mengurangi suplai oksigen pada metabolisme ibu karena kekurangan kadar $\mathrm{Hb}$ untuk mengikat oksigen yang dapat mengakibatkan efek tidak langsung pada bayi, antara lain kematian bayi, bayi lahir prematur dan bertambahnya kerentanan ibu terhadap infeksi. ${ }^{12}$ Di daerah endemis malaria, anemia yang disebabkan oleh defisiensi besi pada ibu hamil sering tumpah tindih dengan anemia yang disebabkan oleh malaria. Pada penelitian ini, ibu hamil yang terinfeksi malaria semuanya mengalami anemia $(100 \%)$, penurunan kadar TIBC $(100 \%)$ dan penurunan kadar $\mathrm{Fe}$ serum $(50 \%)$.

Pada survei malaria pada kehamilan tahun 2004 di Kisumu, Western Kenya. Dari 685 ibu hamil yang berkunjung ke pusat pelayanan kesehatan, 18\% menderita malaria. Dari survei tersebut, didapatkan $69,1 \%$ dari yang menderita malaria tersebut mengalami anemia $(\mathrm{Hb}$ $<11 \mathrm{~g} / \mathrm{dL}$ ) dan $11,8 \%$ mengalami moderate anemia. ${ }^{13}$ Mekanisme anemia yang terjadi disebabkan oleh plasmodium menginvestasi eritrosit sehingga berdampak pada penekanan produksi eritropoetin dan gangguan eritropoesis akibat produksi sitokin pada proses inflamasi. Eritrosit yang diinvestasi oleh plasmodium mengalami kelainan sehingga permukaan sel menjadi tidak teratur. Kerusakan eritrosit tersebut akan menyebabkan anemia, anoksia jaringan dan hemolisis intravaskuler. ${ }^{14}$

Pada penelitian ini, dari 86 ibu hamil yang dilakukan pemeriksaan mikroskopis didapatkan dua orang ibu terinfeksi malaria $(2,3 \%)$, meliputi satu orang dengan malaria vivax $(1,16 \%)$ dan satu orang malaria falsiparum $(1,16 \%)$. Pada periode dua tahun, Desember 2002 -
Agustus 2004, di daerah unstable malaria juga dilaporkan sekitar 7,9\% ibu hamil yang berkunjung ke pusat pelayanan kesehatan menderita malaria vivax. ${ }^{15}$ Malaria pada kehamilan dapat disebabkan oleh keempat spesies Plasmodium, tetapi $P$. falciparum dan $P$. vivax merupakan parasit penyebab infeksi tersering pada ibu hamil. $P$. falciparum merupakan parasit yang dominan dan berdampak terberat terhadap morbiditas dan mortalitas ibu dan janin. ${ }^{16}$ Kemampuan $P$. falciparum untuk melekat di reseptor organ atau pembuluh darah merupakan penyebab malaria berat pada pasien yang terinfeksi $P$. falciparum. ${ }^{17}$ Sebaliknya, pada $P$. vivax, eritrosit yang terinfeksi akan berubah bentuk dan dengan cepat menjadi bentuk matur, tetapi eritrosit yang berparasit ini tidak dapat melekat pada reseptor organ atau pembuluh darah. Oleh sebab itu, pada penderita yang terinfeksi P.vivax jarang berkembang menjadi malaria berat. ${ }^{18}$

$P$. vivax berkemampuan relapse setelah infeksi atau setelah pengobatan infeksi P. falciparum. Relapse tersebut terjadi karena sporozoid yang berada di sel hepatosit menetap (dormant) di hepar dan tidak berkembang menjadi bentuk mature. Dalam waktu yang lama, parasit ini berkembang dan mengakibatkan infeksi recurrent. Pola relapse tergantung dari strain parasit yang berbedabeda sesuai dengan area geografisnya. Pada daerah tropis, relapse dapat terjadi $3-6$ minggu setelah infeksi awal sedangkan pada daerah subtropis relapse terjadi lebih lambat dengan interval mencapai satu tahun lebih setelah infeksi awal. ${ }^{19}$

Pada penelitian ini, kedua ibu hamil yang terinfeksi malaria selain mengalami anemia juga mempunyai kadar Fe serum yang rendah $(50 \%)$ dan kadar TIBC yang rendah (100\%). Penelitian yang dilakukan oleh Ayoya, ${ }^{20}$ didapatkan bahwa 47\% dari 190 ibu hamil yang diskrining malaria mengalami penurunan kadar $\mathrm{Hb}(\mathrm{Hb}<11$ $\mathrm{g} / \mathrm{dL}$ ) dan $13 \%$ mengalami penurunan kadar Fe serum (Fe serum < 12 mikromol/L). Pada penelitian ini, ibu hamil yang terinfeksi malaria vivax juga disertai dengan penurunan kadar Fe serum. Penurunan kadar Fe serum menunjukan bahwa terjadi penurunan cadangan besi yang ada di dalam tubuh. Parasit malaria membutuhkan zat besi untuk kelangsungan hidupnya dari tubuh hospes. Zat besi dibutuhkan untuk aktivitas enzimatik, pernapasan dan reaksi redoks. Lebih kurang $25-75 \%$ hemoglobin dicerna di dalam vakuola makanan selama fase pertumbuhan parasit. Zat besi diperoleh dari pemecahan hemoglobin, plasma transferin yang mengikat zat besi dan feritin intra sel. ${ }^{21}$

Zat besi dapat memengaruhi respons imun sehingga akan berpengaruh terhadap infeksi seseorang. Proses atau respons imun spesifik membutuhkan zat besi dalam mengeleminasi mikroorganisme yang masuk ke dalam tubuh. Di lain pihak mikroorganisme juga membutuhkan zat besi ketika masuk ke dalam tubuh pejamu untuk 
proses multiplikasi. Oleh karena itu, kekurangan zat besi dapat berhubungan dengan perubahan sistem imun dan kejadian infeksi, termasuk infeksi malaria. ${ }^{22} \mathrm{Ibu}$ hamil yang terinfeksi malaria biasanya menderita anemia sehingga akan menyebabkan gangguan sirkulasi nutrisi pada janin dan berakibat pertumbuhan dan perkembangan janin dalam kandungan terhambat, berat badan lahir rendah dan kelahiran prematur. Kematian janin intrauterin juga dapat terjadi akibat hiperpireksi, anemia berat, penimbunan parasit di dalam plasenta yang menyebabkan gangguan sirkulasi ataupun akibat infeksi transplasental. Penimbunan parasit dalam plasenta terjadi pada ibu hamil yang terinfeksi malaria falsiparum. ${ }^{23}$

\section{Kesimpulan}

Dari 55 orang ibu hamil yang mempunyai riwayat terinfeksi malaria, didapatkan satu orang ibu hamil menderita malaria vivax dan satu orang ibu hamil menderita malaria falsiparum. Pada ibu hamil yang tidak menderita malaria, 90,5\% mengalami anemia dan mengalami penurunan kadar TIBC (41,5\%). Hanya 17\% yang mengalami penurunan kadar Fe serum. Pada ibu hamil yang menderita malaria vivax, terjadi penurunan kadar $\mathrm{Hb}$ $(\mathrm{Hb}<11 \mathrm{~g} / \mathrm{dL})$ yang disertai dengan penurunan kadar Fe serum dan kadar TIBC. Pada ibu hamil yang menderita malaria falsiparum, terjadi penurunan kadar $\mathrm{Hb}$ dan kadar TIBC dan tidak disertai dengan penurunan kadar Fe serum, sedangkan pada ibu penderita malaria terjadi penurunan kadar $\mathrm{Hb}(\mathrm{Hb}<11 \mathrm{~g} / \mathrm{dL})$ dan kadar TIBC yang tidak diikuti dengan penurunan kadar Fe serum.

\section{Daftar Pustaka}

1. Larocque R, Casapia M, Gotuzzo E, Gyorkos T. Relationship between intensity of soil-transmitted helminth infections and anemia during pregnancy. American Journal of Tropical Medicine and Hygiene. 2005; 73: 783-9.

2. Nugroho A, Harijanto PN, Datau EA. Imunologi pada malaria. Dalam: Harijanto PN, eds. Malaria: epidemiologi, manifestasi klinis \& penanganan. Edisi ke-1. Jakarta : EGC; 2009. p. 129-47.

3. Sylvia AP. Patofisiologi: konsep klinis proses-proses penyakit. Edisi ke6. Jakarta: EGC; 2005.

4. Yawan FS. Analisis faktor risiko kejadian malaria di wilayah kerja Puskesmas Bosnik Kecamatan Biak Timur Kabupaten Biak - Numfor Papua [Tesis]. Semarang: Universitas Dipenogoro; 2006.

5. Kyabayinze KJ, Tibenderana JK, Nassali M, Tumwine LK, Riches C, montague M, et al. Placental Plasmodium falciparum malaria infection: Operational accuracy of HRP2 rapid diagnostic tests in a malaria endemic setting. Malaria Journal. 2010; 10 (1): 306.
6. Lamikanra AA, Brown D, Potocnik A, Casals-Pascual C, Langhorne J, Roberts DJ. Malarial anemia: of mice and men. Blood. 2007; 110: 18-28.

7. Dinas Kesehatan Propinsi Bengkulu.Profil kesehatan Provinsi Bengkulu, Bengkulu: Dinas Kesehatan Propinsi Bengkulu; 2012.

8. Baird JK, Hoffman SL. Primaquine therapy for malaria. Clinical Infectious Diseases. 2004; 39: 1336-45.

9. Wiknjosastro. Ilmu Kebidanan. Edisi ke-3. Jakarta: EGC; 2007.

10. Saifuddin AB. Demam dalam kehamilan dan dalam persalinan. Jakarta: Buku Panduan Praktis Pelayanan Kesehatan Maternal dan Neonatal; 2002.

11. Manuaba IG. Ilmu kebidanan dan penyakit kandungan dan keluarga berencana untuk pendidikan bidan. Jakarta: EGC; 1998.

12. De Beaudrap P, Turyakira E, White LJ, Nabasumba C, Tumwebaze B, Muehlenbachs A, et al. Impact of malaria during pregnancy on pregnancy outcomes in a Ugandan prospective cohort with intensive malaria screening and prompt treatment. Malaria Journal. 2013; 12: 139-50.

13. Ouma P, van Eijk AM, Hamel MJ, Parise M, Ayisi JG, Otieno K, et al. Malaria and anemia among pregnant women at first antenatal clinic visit in Kisumu, western Kenya. Tropical Medicine \& International Health. 2007 Dec; 12(12): 1515-23.

14. Sylvia AP. Patofisiologi : konsep klinis proses-proses penyakit. Edisi ke6. Jakarta: EGC; 2005.

15. Brutus J, Santalla D, Schneider J, Avila C, Deloron P. Plasmodium vivax Malaria during Pregnancy, Bolivia. Emerging Infectious Diseases. 2013; 19 (10):1605-11.

16. Schantz-Dunn J, Nour NM. Malaria and pregnancy: a global health perspective. Reviews in Obstetrics \& Gynecology. 2009; 2(3): 186-92.

17. Rogerson SJ, Brown HC, Pollina E, Abram ET, Tadesse E, Lema VM, et al. Placental tumor necrosis factor alpha but not gamma interferon is associated with placental malaria and low birth weight in Malawian women. Infection and Immunity. 2003; 71: 267-70.

18. Suwanarusk R, Cooke BM, Dondorp AM, Silamut K, Sattabongkot J, White NJ, et al. The deformability of red blood cells parasitized by Plasmodium falciparum and P. vivax. The Journal of Infectious Diseases. 2004; 189: 190-4.

19. Baird JK, Schwartz E, Hoffman SL. Prevention and treatment of vivax malaria. Current Infectious Disease Reports. 2007;9;39-46.

20. Ayoya MA, Spiekermann-Brouwer GM, Traoré AK, Stoltzfus RJ, Garza C. Determinants of anemia among pregnant women in Mali. Food and Nutrition Bulletin. 2006 Mar; 27(1): 3-11.

21. Rosenthal PJ, Meshnick SR. Hemoglobin catabolism and iron utilization by malaria parasites. Molecular and Biochemical Parasitology. 1996; 83: 131-9.

22. Prentice AM. Iron metabolism, malaria, and other infections: what is all the fuss about? The Journal of Nutrition. 2008; 138: 2537-41.

23. Ezebialu IU, Eke AC, Ezeagwuna DA, Nwachukwu CE, Ifediata F, Ezebialu CU. Prevalence, pattern, and determinant of placental malaria in a population of southeastern Nigerian parturient. International Journal of Infectious Diseases. 2012; 16: e860-65. 